\title{
CHANGES IN CONTENTS OF ZINC AND COPPF R IN ORGANS AND BLOOD OF NICKEL-EXPOSED EUROPEAN CATFISH, SILURUS GLANIS L.
}

\section{ZMIANY ZAWARTOŚCI CYNKU I MIEDZI W NARZĄDACH I KRWI SUMA EUROPEJSKIEGO (SILURUS GLANIS L.) POD WPEYWEM DZIALANIA NIKLU}

\footnotetext{
${ }^{1}$ Department of Fish Diseases, Agricultural University of Szczecin, Poland

${ }^{2}$ Department of Toxicology, Agricultural University of Szczecin, Poland
}

Effects of nickel, administered as aqueous solutions of nickel (III) nitrate (V), on European catfish, Silurus glanis L. were studied. The fish were at first exposed for $24 \mathrm{~h}$ (shortterm exposure). The results obtained during the short-term exposure were used to determine the amount of nickel to be used during a 60-d (long-term) exposure. A significant effect of nickel on the distribution of zinc and copper in the fish blood and organs was found. The changes may have produced disturbed metabolism of the microelements under study during biochemical and energetic processes in the fish. Neither the short- nor the long-term exposure of the fish to nickel resulted in a significant accumulation of the metal in muscles; nor were changes in the microelement concentration in muscles observed.

\section{INTRODUCTION}

To be able to normally develop and function, an organism needs numerous minerals. A deficit or an excess of one or more microelements may disturb the organism's internal equilibrium (Harper et al. 1983). Zinc and copper belong to those microelements which are essential for proper functioning of the body. Recent studies on the role of zinc have resulted in the conviction that it is one of the most important trace elements. Zinc was found to be involved in biosynthesis of nucleic acids and proteins as well as in stabilisation of 
lysosomal and cellular membranes. The element was implicated as affecting intracellular lipid oxidation and electron transport in the respiratory chain. In addition, an inhibitory effect of zinc on phagocytal granulocyte activity and reduction of oxygen consumption in lymphocytes was reported. The microelement was also observed to enhance wound healing (Harper et al. 1983).

Zinc can be found in many animal and human cells and tissues. Considerable amounts of zinc are contained in bones and teeth as well as in kidneys and muscles; about $20 \%$ of the total body zinc is to be found in skin. The metal is indispensable for maintenance of an appropriate concentration of vitamin $\mathrm{A}$ in the blood serum and in mobilisation of the liver vitamin A reserves. It is also an essential component of some enzymes, including alkaline phosphatase, carbonate anhydrase, and hyperoxide dismutase, the latter containing also copper.

Copper is present in all animal tissues. It forms a part of cytochrome $\mathrm{C}$ oxidase responsible for $90 \%$ of oxygen consumption on Earth, and is contained in hyperoxide dismutase, an enzyme catalysing toxic oxygen radicals produced during aerobic processes. The highest amounts of copper in an animal body are contained in liver, brain, heart, and kidneys, where it is a component of aminooxidase, thyrosinase, uricase, and dopamine hydroxylase. Liver plays a major role in copper metabolism. In the blood serum, copper is tightly coupled to ceruloplasmin, the coupling responsible for about $90 \%$ of the total copper amount. When loosely bound to albumin, copper easily chelates (Szczygieł 1975).

Nickel is one of those microelements which occur in trace amounts in living organisms. The physiological role of the element is to activate arginase and carboxylase and to enhance the activity of hormones. The metal plays a role in oxidation of cellular membrane organic compounds and in stabilisation of the nucleic acid structure; it is also involved in lipid metabolism. Nickel is suspected of binding with plasmin, thus regulating its function (Mattheis 1988; Dobrzański et al. 1996). Different organisms absorb and accumulate nickel at different rates and to a different degree; studies on nickel accumulation by fish organs, reported by Kedar and Nishith (1989) and aimed at elucidating nickel tolerance, need continuation and broadening.

Since 1930, nickel consumption, and thus its release to the environment, has been almost doubling during each decade. The total nickel content in fresh waters exceeds at present $8.4 \cdot 10^{11} \mathrm{~kg}$, increasing concentrations being found in water bodies situated in the vicinity of industrial facilities (Sreedevi et al. 1992). When contained in water-soluble compounds, nickel is easily absorbed by plants, some of which are highly nickel-tolerant. Nickel binds to porphyrins and chlorophylls, replacing iron and magnesium (KabataPendias and Pendias 1979). 
The European catfish, Silurus glanis Linnaeus, 1758 is a species the popularity of which has been considerably increasing over the recent years. It is one of the largest fish in Europe and grows very rapidly (Steffens 1986). The marketability of the species is enhanced by the absence of scales on its body and by its tasty meat with few bones. The culture of the species is expanding, both as a market commodity and for stocking natural water bodies (Wiśniewolski 1978; Hilge 1985).

The work described in this paper was aimed at following effects of nickel on contents of zinc and copper in whole blood and organs of the European catfish during a short- and a long-term exposure.

\section{MATERIAL AND METHODS}

The assays were made on the European catfish cultured, at the experimental station of the Agricultural University of Szczecin, in a heated effluent of the Dolna Odra power station. The fish weighing 160-265 g and measuring $23-34.5 \mathrm{~cm}$ in total length were kept in $100 \mathrm{dm}^{3}$ tanks in which they were first acclimated for 2 weeks. Water temperature, hardness, $\mathrm{pH}$, and mean dissolved oxygen content were maintained at $19 \pm 2^{\circ} \mathrm{C} ; 30^{\circ}$; 6.9-7.2; and $9.9 \mathrm{mg} \mathrm{O}_{2} \cdot \mathrm{dm}^{-3}$, respectively. During both the acclimation and experimental stages, the fish were fed pelleted feed identical to that administered in the original culture. The fish were exposed to a water solution of nickel (II) nitrate (V).

Short-term exposure

The fish were divided into 7 groups 5 individuals each. The 6 experimental groups were subjected to 24-h nickel exposure, the respective nickel concentrations being 0.03 ; $0.06 ; 1 ; 10 ; 50$; and $100 \mathrm{mg} \cdot \mathrm{dm}^{-3}$ water.

\section{Long-term exposure}

The fish were divided into 7 groups 10 individuals each. Every group consisted of a control ( 5 individuals) and a treatment sub-group ( 5 individuals). The treatments involved exposure to $0.06 \mathrm{mg} \mathrm{Ni} \cdot \mathrm{dm}^{-3}$ for $1,3,7,14,30,45$, and 60 days.

At both stages of the experiment, toxicological assays were made on fish skin, gills, muscles, intestine, liver, spleen, kidney, and whole blood. The blood and organ samples were mineralised dry (in $\mathrm{HNO}_{3}$ ) (Protasowicki 1985). Contents of the microelements under study were determined with flame absorption atomic spectophotometry (FAAS) in a Varian Techtron A1200 spectrophotometer. Nickel, zinc, and copper contents in the samples $\left(\mu \mathrm{g} \cdot \mathrm{g}^{-1}\right.$ wet weight) were calculated from calibration curves plotted with the procedure of additives. The data obtained were subjected to the single- and multifactor analysis of variance and to the regression analysis at 95\% confidence level (Parker 1978; Podgórski 1995). 


\section{RESULTS}

\section{Short-term exposure}

The short-term exposure to various nickel concentrations in water resulted in an increase in nickel contents in all the blood and organs examined (Table 1), as indicated by the direct linear correlation. Differences in the amount of nickel accumulated in various organs were statistically significant at exposures to nickel concentrations exceeding 0.03 $\mathrm{mg} \cdot \mathrm{dm}^{-3}$. The gills were found to accumulate the highest amounts of nickel, the lowest accumulation being observed in muscles for which the correlation between water and tissue concentrations was relatively weak (the regression analysis determination coefficient of $71 \%)$.

The highest zinc contents after the short-term exposure were found in the kidney, the exposure to $0.06 \mathrm{mg} \mathrm{Ni} \cdot \mathrm{dm}^{-3}$ resulting in accumulation weaker than that recorded at higher ambient concentrations. Zinc concentrations were observed to increase in the spleen and the gills, all the differences between the treatment and control samples being statistically significant. Similar, although not as pronounced, changes were observed in the intestine (Fig. 1). On the other hand, no effect of different ambient nickel concentrations on accumulation could be detected either the catfish blood, liver, or in the muscles.

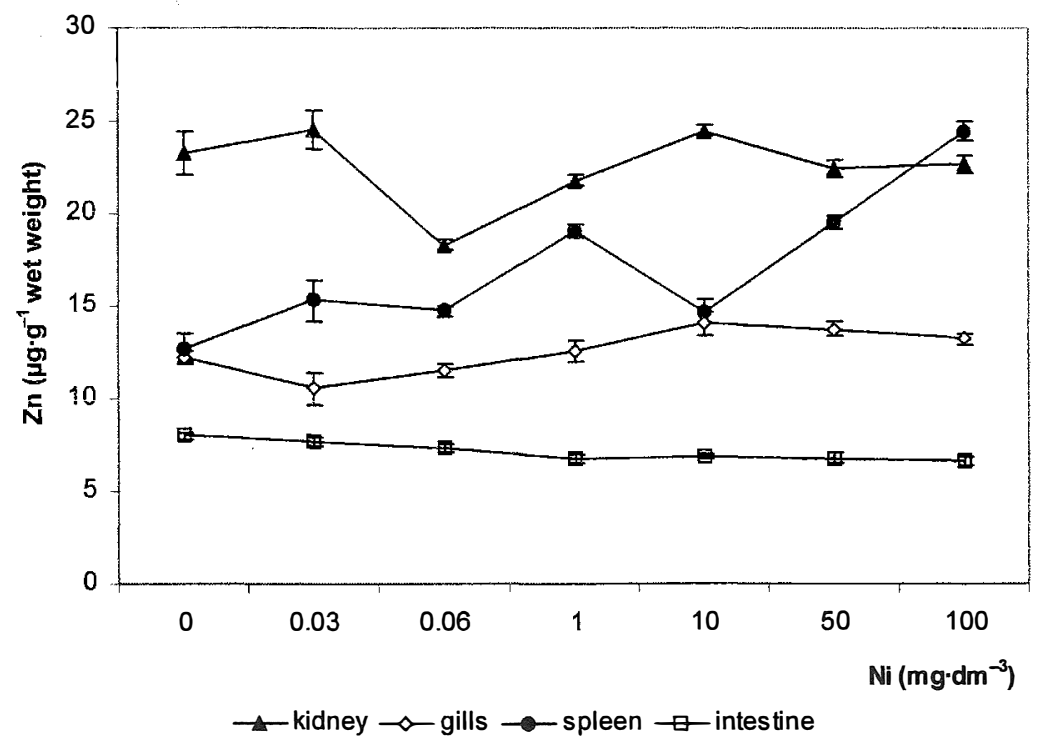

Fig. 1. Changes in zinc contents in kidney, gills, and spleen during $24 \mathrm{~h}$ exposure to different nickel concentrations

The increasing nickel concentrations in water were accompanied by increased levels of the metal in the liver (Fig. 2). A reverse trend was observed in the intestine and in the 
spleen. Significant differences in copper accumulation by the skin were recorded at 0.06 and $1 \mathrm{mg} \cdot \mathrm{dm}^{-3}$ nickel concentrations in water (Fig. 3). No statistically significant differences between the control and the treatment samples were found in the kidney, in spite of the copper concentrations decreasing there with time. No nickel effect on copper level in the blood, gills, and the muscles were detected.

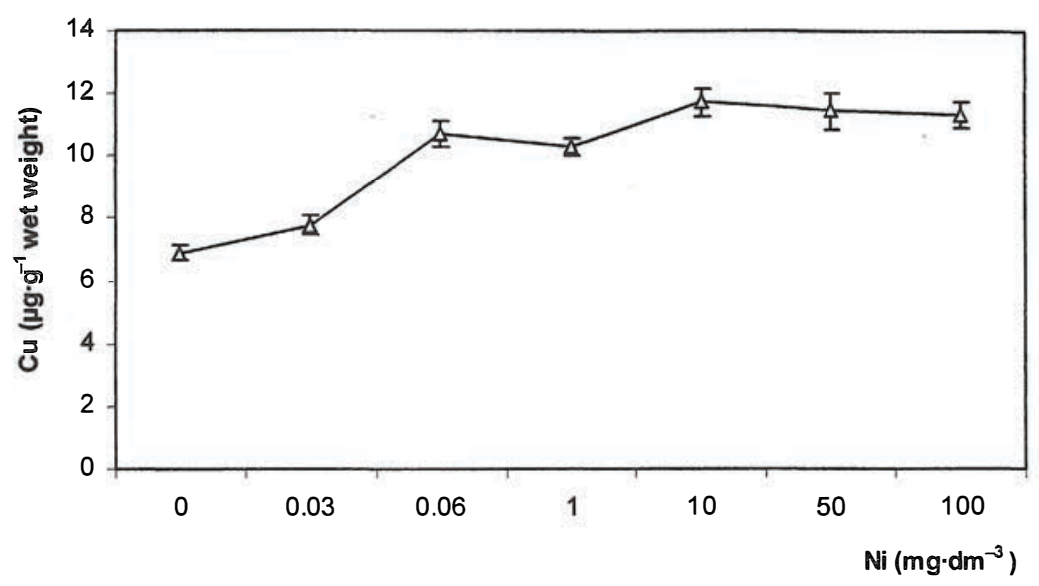

Fig. 2. Changes in copper contents in liver during $24 \mathrm{~h}$ exposure to different nickel concentrations

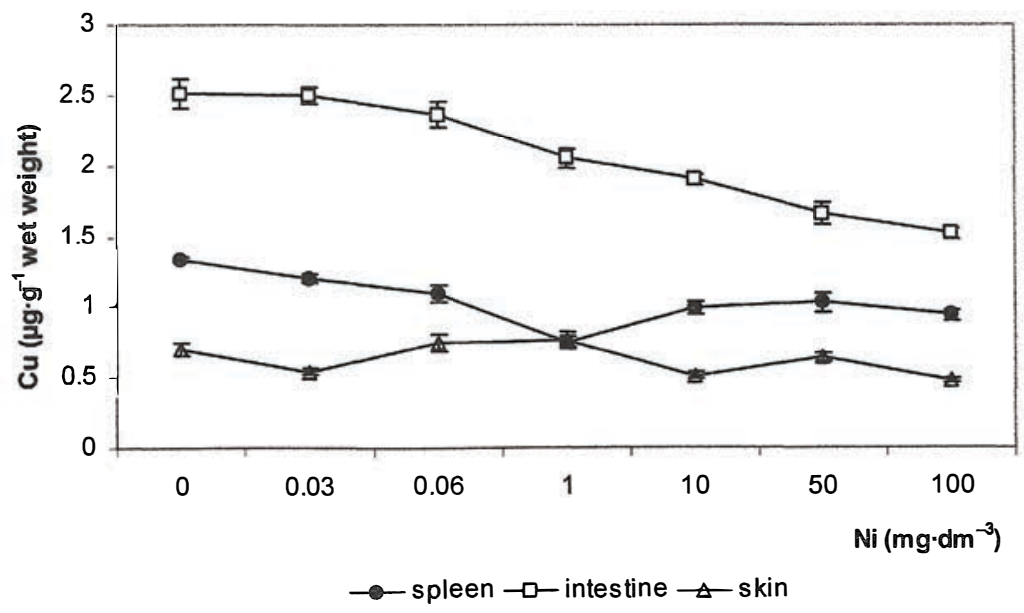

Fig. 3. Changes in copper contents in spleen, intestine, and skin during exposure to different nickel concentrations 


\section{Long-term exposure}

After 60 days of exposure, the highest nickel concentrations were recorded in the kidney, the lowest concentrations occurring in muscles (Table 2), which was also the case after the short-term exposure. The correlation between duration of exposure and nickel accumulation in muscles was relatively weak (the regression analysis coefficient of determination of $68 \%$ )

The blood response to the long-term nickel exposure involved an increase in the nickel concentration after 14 days (Fig. 4). Nickel concentrations increased also in the skin, intestine, and kidney. On the other hand, a decreasing trend was observed in the gills (Fig. 5). No correlation between the duration of the nickel exposure and the liver zinc content was observed.

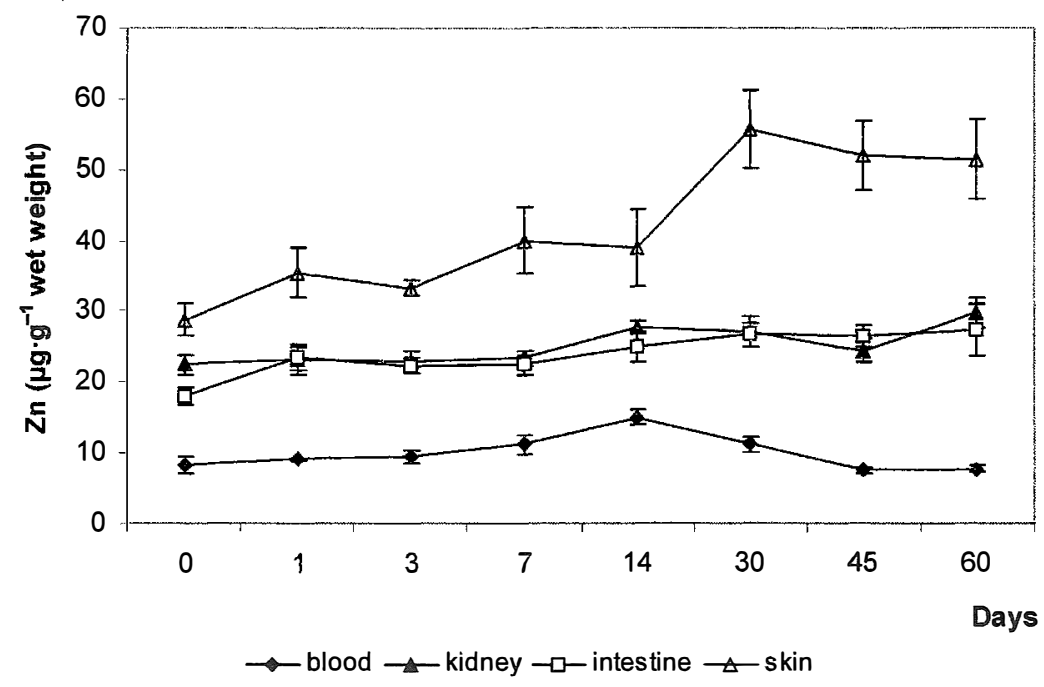

Fig. 4. Effects of duration of exposure on changes in zinc contents in blood, skin, intestine, and kidney at a constant nickel concentration in water

A linear decrease in the copper concentration was recorded in the spleen during 60 days of exposure. A slight increase in copper level was observed in the blood, while varying concentrations were found in the skin and in muscles (Fig. 6). No correlation between copper concentration and duration of the exposure was detected in the kidney, gills, intestine, and liver of the fish tested. 
Changes in nickel contents in European catfish blood and organs in relation to nickel concentration in ambient water

\begin{tabular}{|c|c|c|c|c|c|c|c|c|}
\hline \multirow{2}{*}{ Ni $\left(\mathrm{mg} \cdot \mathrm{dm}^{-3}\right)$} & \multicolumn{7}{|c|}{$\mathrm{Ni}\left(\mu \mathrm{g} \cdot \mathrm{g}^{-1}\right)( \pm \mathrm{SD})$} \\
\cline { 2 - 8 } & Blood & Kidney & Gills & Liver & Spleen & Intestine & Skin & Muscles \\
\hline 0 & $0.352(0.042)$ & $0.366(0.043)$ & $1.081(0.079)$ & $0.354(0.044)$ & $0.430(0.069)$ & $0.410(0.020)$ & $0.195(0.013)$ & $0.102(0.019)$ \\
0.03 & $0.361(0.029)$ & $0.370(0.016)$ & $1.088(0.242)$ & $0.355(0.018)$ & $0.452(0.014)$ & $0.411(0.051)$ & $0.196(0.07)$ & $0.173(0.037)$ \\
0.06 & $0.371(0.012)$ & $0.375(0.032)$ & $1.095(0.099)$ & $0.355(0.024)$ & $0.461(0.025)$ & $0.413(0.014)$ & $0.197(0.013)$ & $0.117(0.033)$ \\
1 & $0.657(0.037)$ & $0.514(0.081)$ & $1.314(0.160)$ & $0.378(0.040)$ & $0.542(0.011)$ & $0.458(0.026)$ & $0.223(0.048)$ & $0.055(0.041)$ \\
10 & $2.992(0.514)$ & $1.676(0.276)$ & $3.013(0.355)$ & $0.594(0.062)$ & $0.671(0.044)$ & $0.890(0.150)$ & $0.475(0.049)$ & $0.135(0.015)$ \\
50 & $5.755(0.746)$ & $4.116(0.498)$ & $4.970(0.820)$ & $1.554(0.379)$ & $0.780(0.059)$ & $2.810(0.248)$ & $1.595(0.283)$ & $0.243(0.038)$ \\
100 & $7.252(0.960)$ & $5.366(0.425)$ & $8.834(0.630)$ & $2.754(0.444)$ & $1.291(0.091)$ & $5.210(0.415)$ & $2.995(0.373)$ & $0.284(0.061)$ \\
\hline
\end{tabular}

Table 2

Kinetics of nickel contents in European catfish blood and organs during exposure to nickel

\begin{tabular}{|c|c|r|r|r|r|r|r|c|}
\hline \multirow{2}{*}{ Days } & \multicolumn{1}{|c|}{ Ni $\left(\mu \mathrm{g} \cdot \mathrm{g}^{-1}\right)( \pm$ SD) } \\
\cline { 2 - 8 } & Blood & \multicolumn{1}{|c|}{ Kidney } & \multicolumn{1}{c|}{ Gills } & Liver & \multicolumn{1}{c|}{ Spleen } & \multicolumn{1}{c|}{ Intestine } & Skin & Muscles \\
\hline 0 & $0.491(0.136)$ & $0.766(0.237)$ & $0.985(0.113)$ & $0.509(0.119)$ & $0.436(0.071)$ & $0.276(0.130)$ & $0.589(0.117)$ & $0.448(0.172)$ \\
1 & $1.941(0.388)$ & $1.344(0.122)$ & $4.069(1.321)$ & $0.901(0.124)$ & $0.644(0.022)$ & $2.682(0.752)$ & $0.738(0.196)$ & $0.665(0.124)$ \\
3 & $2.992(0.288)$ & $1.771(0.068)$ & $6.325(1.365)$ & $1.188(0.083)$ & $1.060(0.026)$ & $3.588(0.435)$ & $1.036(0.270)$ & $0.805(0.208)$ \\
7 & $4.258(0.460)$ & $2.345(0.482)$ & $9.130(1.177)$ & $1.547(0.121)$ & $1.882(0.060)$ & $4.052(0.539)$ & $1.625(0.179)$ & $0.958(0.239)$ \\
14 & $5.629(0.886)$ & $3.327(1.210)$ & $12.410(1.536)$ & $1.977(0.193)$ & $3.257(0.057)$ & $4.392(0.873)$ & $2.608(0.479)$ & $1.111(0.120)$ \\
30 & $7.092(0.982)$ & $7.848(0.452)$ & $16.800(1.432)$ & $2.658(0.384)$ & $5.763(0.044)$ & $6.654(1.097)$ & $4.366(0.555)$ & $1.282(0.255)$ \\
45 & $7.193(2.605)$ & $17.860(1.097)$ & $18.030(1.542)$ & $3.141(0.449)$ & $6.705(0.063)$ & $9.929(0.813)$ & $4.939(0.490)$ & $1.351(0.386)$ \\
60 & $6.338(2.461)$ & $36.560(5.884)$ & $16.230(1.727)$ & $3.548(0.390)$ & $5.582(0.053)$ & $11.940(1.325)$ & $3.931(0.419)$ & $1.376(0.212)$ \\
\hline
\end{tabular}




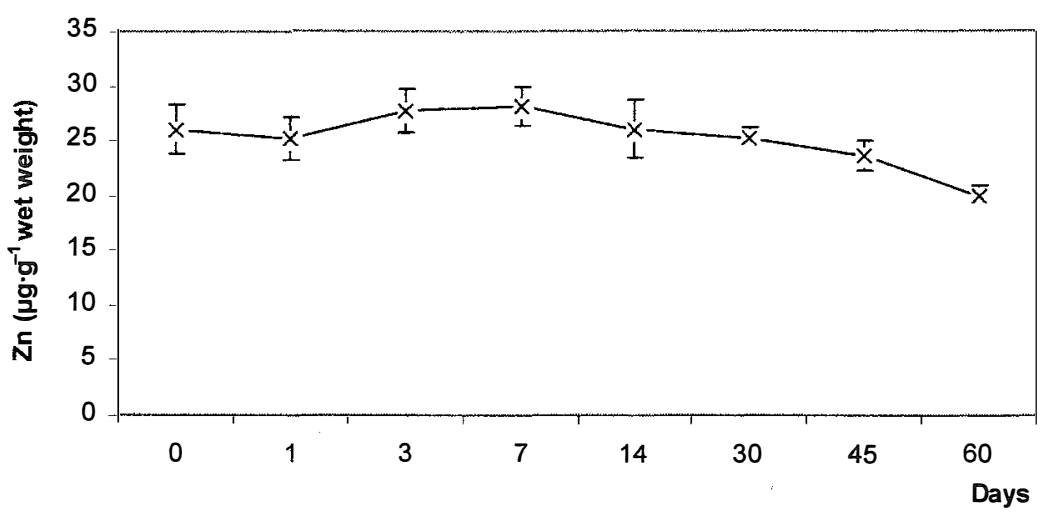

Fig. 5. Effects of duration of exposure on changes in zinc contents in gills at a constant nickel concentration in water

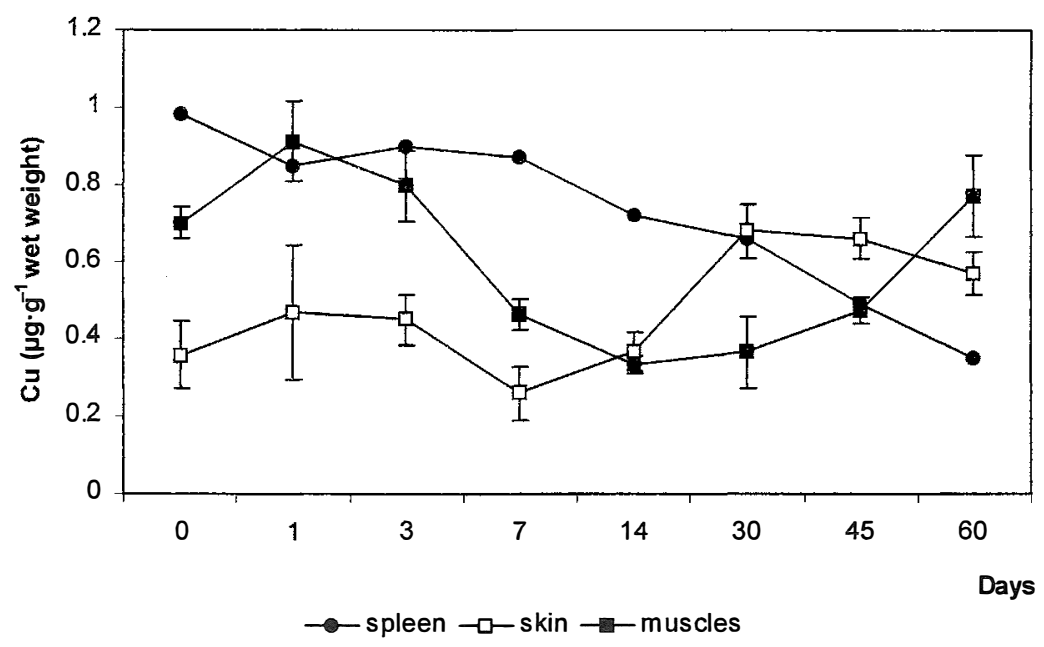

Fig. 6. Effects of duration of exposure on changes in copper contents in spleen, skin, and muscles at a constant nickel concentration in water

\section{DISCUSSION}

During a 24-h exposure to increasing ambient nickel concentrations, an increased accumulation of the toxin was found in all the assayed tissues. The tissue contents correlated tightly with the concentration in water; the strength of the relationship, in a decreasing order, can be presented as gills $>$ blood $>$ kidney $>$ intestine $>$ skin $>$ liver $>$ spleen $>$ muscles. During the sub-acute exposure, kidney accumulated the highesi amounts of nickel, a substantial increase in the concentration occurring after 14 days. This implies impairment in the kidney's secretory function, a conclusion also arrived at by Gardner and Yvette 
(1970) and Ray et al. (1990) whose studies on nickel effects on Clarias batrachus showed kidneys and gills to be most critically affected. Those organs are sites of osmotic and ionic exchange processes. The stress induced by a long-term exposure to a toxic compound results in an increased permeability of the respiratory epithelium, the toxin itself damaging the delicate gill tissue which first comes in contact with the toxin.

Relatively high amounts of nickel were concentrated in the intestinal walls into which the toxin penetrated along two pathways: via ionic exchange with the blood and with water and food. The latter pathway emphasises the role of feeding in pollutant migration up the food chain (Pujin et al. 1990).

The basic function of the liver is to bind toxic compound in the body to the thiol groups of metallothionein. This eliminates the toxins from body fluids, thus reducing the amount of toxic substances circulating in the system. McCarter and Roch (1984) demonstrated unequivocally that the presence of copper-thionein in fish liver was induced by exposure to copper.

The lowest accumulation of nickel occurred, during the long-term exposure, in the skin and muscles. Svobodova et al. (1995) and Kołacz et al. (1996) showed the extent of metal accumulation in fish muscles to be species-specific. Windom et al. (1987) suggested that those differences were affected by the toxicity of a chemical compound, in addition to fish size and age.

Effects of nickel accumulation in the body of the European catfish were discernible through changes in contents of zinc and nickel in different tissues and organs. At both stages of the experiment, the spleen zinc level underwent a change, a two-fold increase being recorded during the short-term (24 h) exposure. As suggested by Mills (1989), such a response could be related to a substantial breakdown of erythrocytes and release of zinc from carbonate anhydrase. Another explanation of the process might be sought in mobilisation of the spleen as an organ producing lymphocytes to intensify lymphopoiesis. Zinc is known as an element indispensable for normal growth and function of the T lymphocytes (Williams et al. 1990). This latter explanation seems more plausible in view of the almost unchanged zinc level in the blood. During subacute exposure to nickel, the zinc concentration in the spleen increases slightly at the beginning and decreases at the end of the experiment. In Bentley's (1991) interpretation of the process, zinc-replaced by an ion of some other metal is intercepted and bound by the serum proteins and is subsequently transported to liver or kidney to be coupled to thionein. Considering the significant increase of the microelement in the kidney, this course of events could have been the case in the experiment described. Stonard and Webb (1976) suggest that binding of zinc by the cytosol proteins explains an increase in zinc concentration in liver and kidney, the primary sites of metallothionein synthesis induced by the presence of the toxin. 
The time-dependent increase in zinc concentration in the skin was most probably related to the replacement of the microelement in question by the more reactive nickel ion and by the subsequent accumulation, followed by the release with mucus the production of which noticeably increased. A similar explanation may be invoked with respect to the growing concentration of zinc in the intestinal walls, the intestine in a healthy organism being the site of absorption and excretion.

The copper metabolism is controlled chiefly by the liver. Copper, transported by albumins and strongly bound by cerulopasmin, is present in all the tissues. During the shortterm exposure to increasing concentrations of nickel, the copper content in the liver was observed to almost double. A similar tendency was described by Ashby et al. (1981) who studied cadmium effects on tissue contents of zinc and copper. They concluded that the presence of a toxic substance in the body provoked biliary binding and release of the microelements which may be ultimately removed from the body via the intestine. An increase of copper content in liver cells inhibits copper binding to apoceruloplasmin, which leads to reduction in concentration of the protein in the serum. As a consequence, haemolytic anaemia may ensue (Murray et al. 1995).

Copper plays a major role in metabolic regulation and iron transport in the body (Singh and Reddy 1990; Tariq et al. 1991). The significantly decreasing content of the microelement in the spleen in both phases of the experiment could suggest copper release from the body's reserves and involvement in the processes described above. At the two highest nickel concentrations in the first phase of the experiment as well as after 3 weeks of exposure at the second phase the catfish lost appetite. Tomaszewski (1997) found a decreasing copper content in the body to accompany intestinal dysfunction associated with disturbed intestinal absorption, which could have happened during the experiment described.

\section{CONCLUSIONS}

1. The study described in this paper documented a relationship between the amount of nickel in water and the duration of exposure to nickel on the one hand and nickel accumulation in tissues on the other. The process results in disturbances in distribution and transport of copper and zinc, particularly at a long-term exposure to nickel.

2. Particularly interesting is the negligible accumulation of nickel in the European catfish muscles, a finding important in view of the expanding culture of the species for human consumption. 


\section{ACKNOWLEDGMENT}

We wish thank Dr M. Sobecki for his assistance with the statistical processing of data.

\section{REFERENCES}

Ashby S.L., L.J. King, $\mathbb{D}$. Parker, 1981: The effect of cadmium administration on the biliary excretion of $\mathrm{Cu}$ and $\mathrm{Zn}$ and tissue disposition of metals. Environ. Res., 26: 95-104.

Bentley P.J., 1991: A high-affinity zinc-binding plasma protein in channel catfish (Ictalurus punctatus). Comp. Biochem. Physiol., 100C, 3: 495-500.

Dobrzański ZZ . R. Kolacz, E. Bodak, 1996: Metale ciężkie w środowisku zwierząt [Heavy metals in animal environment]. Med. Wet., 52, 9: 570-574. (In Polish).

Gardner G.R., P.P. Yevich, 1970: Histological and hematological responses of an estuarine teleost to cadmium. J. Fish. Res. Bd Can., 27: 2185-2196.

Harper H.A.,V.W. Rodwell, P.A. Mayes, 1983: Zarys chemii fizjologicznej [An outline of physiological chemistry]. PZWL, Warszawa.

Hilge V., 1985: The influence of temperature on the growth the European catfish (Silurus glanis L.). Ztschr. für angew. Ichthyol., 1: 27-31.

Kabata-Pendias A., H. Pendias, 1979: Pierwiastki śladowe w środowisku biologicznym [Trace elements in biological environment]. Wyd. Geologiczne, Warszawa. (In Polish).

Kedar N., K. Nishith, 1989: Induced histopathological alteration in the gill architecture of a tropical freshwater perch, Colisa fasciatus (Bloch and Schn.). Sci. Total Environ., 80: 293-296.

Kolacz R., Z. Dobrzański, E. Bodak, 1996: Bioakumulacja Cd, Pb i Hg w tkankach zwierząt [Biocumulation of $\mathrm{Cd}, \mathrm{Pb}$, and $\mathrm{Hg}$ in animal tissues]. Med. Wet., 52, 11: 686-691. (In Polish).

Mattheis T., 1988: Datensammlung der Grenzkonzentrationen von Schadstoffen für die Fischproduktion - Metalle und Metalloide. Fortschrifft Fischerei Wissenschaft, 7: 29-82.

McCarter J.A., M. Roch, 1984: Chronic exposure of coho salmon to sublethal concentration of copper - III. Kinetics of metabolism of metallothionein. Comp. Biochem. Physiol., 77C, 1: $83-87$.

Mills C.F., 1989: Zinc in human biology. Springer Verlag, Berlin.

Murray R.K., D.K. Granmer, P.A. Mayes, V. Rodwell, 1995: Biochemia Harpera [Harper`s Biochemistry]. PZWL, Warszawa. (In Polish).

Parker R.E., 1978: Wprowadzenie do statystyki dla biologów [Introduction to statistics for biologists]. PWN, Warszawa. (In Polish).

Podgórski, J., 1995: Statystyka z komputerem [Statistics with a computer]. MIKOM, Warszawa. (In Polish).

Protasowicki M., 1985: Comparison of techniques of fish sample preparation for heavy metals analysis by flame AAS. Proc. $24^{\text {th }}$ CSI, III, Garmisch-Partenkirchen: 548-549.

Pujin, V., N. Djukić, S. Maletin, S. Obradović, D. Kostić, 1990: Content of heavy metals in some fish species in the section of the Danube flowing trough Vojvodina. Water Sci. Technol., 22, 5: 79-86.

Ray D., S.K. Banerjee, M. Chatterje, 1990: Bioaccumulation of nickel and vanadium in tissues of the catfish Clarias batrachus. J. Inorganic Biochem., 38: 169-173.

Singh H. S., T.V. Reddy, 1990: Effect of copper sulfate on hematology, blood chemistry and hepato-somatic index of an Indian catfish, Heteropneustes fossilis (Bloch), and its recovery. Ecotoxicol. Environ. Safety, 20: 30-35.

Sreedevi P., B. Sivaramakrishna, A. Suresh, K. Radhakrishnaiah, 1992: Effect of nickel on some aspects of the gill and kidney of the freshwater fish, Cyprinus carpio L. Environ. Pollut., 77: 59-63. 
Steffens W., 1986: Intensywna produkcja ryb [Intensive fish breeding]. PWRiL, Warszawa. (In Polish).

Stonard M. D., M. Webb, 1976: Influence of dietary cadmium on the distribution of the essential metals $\mathrm{Cu}, \mathrm{Zn}$ and $\mathrm{Fe}$ in tissue on the rat. Chemico-Biological Interactions, 15: 349-363.

Svobodova Z., V. Piacka, B. Vykusova, J. Machova, M. Hejtmanek, M. Hrbkova, J. Bastl, 1995: Residues of pollutants in siluriformes from various localities of the Czech Republic. Acta Vet. Brno, 64: 195-208.

Szczygiel A., 1975: Podstawy fizjologii żywienia [Fundamentals of nutrition physiology]. PZWL, Warszawa. (In Polish).

Tariq J., M. Jaffar, M. Moazzam, 1991: Concentration correlation between major cations and heavy metals in fish from the Arabian Sea. Marine Pollut. Bull., 22, 11: 562-565.

Tomaszewski J.J., 1997: Diagnostyka laboratoryjna [Laboratory diagnostics]. PZWL, Warszawa. (In Polish).

Williams W.J., E. Beutler, A.J. Erslev, M.A. Lichtman, 1990: Hematology. McGraw-Hill Publication Company, New York.

Windom H., D. Stein, R. Sheldon, J. Smith, 1987: Comparison of trace metal concentrations in muscle tissue of a benthopelagic fish (Coryphaenoides armatus) from the Atlantic and Pacific oceans. Deep-Sea Res., 34, 2: 213-220.

Wiśniewolski W., 1978: Wyniki wstępnych eksperymentów żywienia suma w różnej temperaturze [Results of a preliminary study on wels feeding at different temperatures]. Gospod. Ryb., 9: 9-11. (In Polish).

Ewa SOBECKA, Mikołaj PROTASOWICKI

\author{
ZMIANA ZAWARTOŚCI CYNKU I MIEDZI W NARZĄDACH I KRWI \\ SUMA EUROPEJSKIEGO (SILURUS GLANIS L.) POD WPEYWEM \\ DZIAEANIA NIKLU
}

\title{
STRESZCZENIE
}

Badano działanie niklu w postaci rozpuszczonego w wodzie azotanu (V) niklu (II) na sumy europejskie Silurus glanis L. Ryby poddano 24-godzinnej ekspozycji na działanie trucizny, na podstawie uzyskanych wyników określono ilość niklu, która użyto podczas 60-dniowego działania na organizm ryb. Zauważono maczący wpływ obecności niklu na rozmieszczenie i dystrybucję cynku i miedzi w narządach i krwi ryb. Skutkiem tych zmian mogą być zaburzenia przemian badanych mikroelementów w procesach biochemicznych i energetycznych organizmu. Zarówno krótko jak i długotrwałe działanie niklu na organizm ryb nie powoduje istotnej jego kumulacji w mięśniach, a także zmian dotyczących zawartości badanych w nich mikroelementów. Ze względu na zwiększająca się hodowlę tego gatunku ryb w celach konsumpcyjnych oraz wzrastającą emisję związków niklu do środowiska fakt ten ma istotne znaczenie gospodarcze.

Author's address:

Ewa Sobecka PhD

Department of Fish Diseases

Agricultural University of Szczecin

Kazimierza Królewicza 4, 71-550 Szczecin, Poland 